\title{
IMPLEMENTATION OF THE DIGITAL TRAINING CONCEPT IN THE BASIC FLIGHT TRAINING IN THE SERBIAN MILITARY ACADEMY
}

\author{
Slaviša I. Vlačića, Aleksandar Z. Kneževićb, \\ Vladimir M. Grbovićc, Panos A. Vitsas ${ }^{\mathrm{d}}$, \\ Mihajlo (Mike) S. Mihajlovice \\ a University of Defence in Belgrade, Military Academy, \\ Air Force Department, Belgrade, Republic of Serbia, \\ e-mail: slavisa.vlacic@va.mod.gov.rs, corresponding author, \\ ORCID iD: Ohttps://orcid.org/0000-0001-9336-0512 \\ b University of Defence in Belgrade, Military Academy, \\ Air Force Department, Belgrade, Republic of Serbia, \\ e-mail: aleksandar.knezevic@va.mod.gov.rs, \\ ORCID iD: -https://orcid.org/0000-0001-6786-4530 \\ c Serbian Armed Forces, Air Force and Air Defence Command, \\ Belgrade, Republic of Serbia, \\ e-mail: grba74@yahoo.com, \\ ORCID iD: Chttps://orcid.org/0000-0003-1700-2478 \\ d International Test Pilots School, London ON, Canada, \\ e-mail: pavitsas@gmail.com, \\ ORCID iD: (Thttps://orcid.org/0000-0001-5266-4640 \\ e Government of Ontario, Toronto ON, Canada; \\ MRTD Defense Eng, Toronto ON, Canada, \\ e-mail: mmihajlovic@rogers.com, \\ ORCID iD: (1) https://orcid.org/0000-0001-8768-676X
}

DOI: 10.5937/vojtehg70-34610; https://doi.org/10.5937/vojtehg70-34610

FIELD: Air traffic, Information technologies ARTICLE TYPE: Original scientific paper

Abstract:

Introduction/purpose: The paper provides a review of recent research in the field of digital training applied in the Serbian Military Academy flight training. Flight training represents the foundation of successful education of military pilots. Its division is based on the environment and a phase of realization. The main part and the core of successful flight training is basic flight training. This training phase has experienced significant changes with the introduction of the Technically Advanced aircraft (TAA) which is characterized by a high degree of digitalization not only of the cockpit but also of other aircraft systems. Consequently, a different methodological approach to training is needed, including a digital training concept. The paper shows the achievements and certain solutions based on some 
elements of digital training concepts used in the basic flight training at the Serbian Military Academy.

Methods: The scientific approach is used in the evaluation of aircraft cockpit digitalization and in the implementation of a new training concept in the basic flight training in the Serbian Military Academy.

Results: Based on the methodological analysis used, the importance and the values of the digital training concept in basic flight training are shown.

Conclusion: Although the digital training concept is not mandatory in the existing flight training model in the Serbian Military Academy, it proves to be a valuable asset. Its potential is significant and, to a certain extent, it can change the nature of basic flight training. Due to digital training, cadets can fly more safely and their flying skills are acquired faster. In accordance with new modern aircraft acquisition in the Serbian Air Force, every aspect of the digital training concept has to be carefully considered, especially in the basic flight training phase, including conversion to new aircraft types.

Key words: flight training, glass cockpit, digital training, training devices.

\section{Introduction}

Flight training represents the foundation of successful education of military pilots. Its division is based on the environment and a phase of realization. Regarding the environment, it can be realized on the ground or in the air. Military flight training consists of four phases: primary, basic, advanced, and combat flight training. The main part and the core of successful flight training is basic flight training. This phase is usually completed on a piston-engine or turboprop trainer. Acquisitions of new types of planes in this phase involve many changes and bring new challenges. It is necessary to adapt the methodological manuals, the study curriculum and the syllabus based on the Lasta airplane as well as many other elements of the flight training system. In recent years, the biggest challenge has been the introduction of a digital glass cockpit from the very beginning of flight training. It demands a new approach, even using a variety of commercially available tools and devices to make the digital concept effective for a new era of basic flight training.

\section{Basic flight training in the Military Academy}

In the Military Academy, the study in military aviation is divided in two main parts. The first one, lasting five semesters, is realized in the Military Academy headquarters situated in Belgrade. The main goal of 
this phase is theoretical preparation for the upcoming flight training in an airbase near Belgrade. This phase is also considered as a preparation phase in terms of core activities (flying) during studying. The second phase is flight training on airplanes and helicopters and it is crucial for the cadets - pilots. Having in mind that the first (preparation) phase has a very important role regarding the quality of flight training as a crown of the education process, there is a permanent task to improve this process and make it more effective and safer (Vlacic et al, 2014).

Flight training represents the foundation of successful education of military pilots. The main constituents of flight training are the environment and a phase of realization. Regarding the environment, it can be realized on the ground or in the air. Military flight training consists of four phases: primary, basic, advanced, and combat flight training.

Basic flight training is considered to be the most important phase of flight training and the core of the successful process of making future pilots. It is aimed at mastering the necessary aircraft handling skills. The curriculum contains basic flying, aerobatic flying, navigation flying, instrument flying, formation flying, and night flying. The flight training duration is between 80 and 130 flight hours, and it depends on the airplane or helicopter types. These can be piston engine or turboprop airplanes, even simple jet trainers or helicopters.

The first step for each of these phases is the ground (theoretical) preparation, which is an integral part of flight training. The division by the phases has not been changed for almost half a century and it would not be changed in the near future. The main teaching methods in the air have not been changed, either. However, the main changes have emerged because of the introduction of new training aircraft, regardless of airplane or helicopter types (Vlačić et al, 2015).

Recognizing the importance of the basic type of training, the Serbian Air Force very carefully approached the design of a new type of piston engined aircraft, named Lasta. This type of aircraft has been included in the Military Academy's flight training syllabus since 2017. The syllabus is based on two aircraft types during the training in the Academy: the basic flight training on the Lasta (Swallow) aircraft precedes the training on the advanced jet trainer G-4 (Figure 1) followed by the basic combat training and the introduction to fighter fundamentals (IFF). 




Figure 1 - Basic flight training on the Lasta precedes the training on the G-4 Puc. 1 - Основная летная подготовка на самолете „Ласта“, предшествующая учениям на "Г-4“.

Слика 1 - Основна летачка обука на авиону,ласта” претходи обуци на Г-4

The Lasta training aircraft, as a new type in the Serbian Air Force service, brings a lot of technical improvements compared to older training aircraft. One of the biggest improvements is the implementation of a digital glass cockpit (Figure 2).

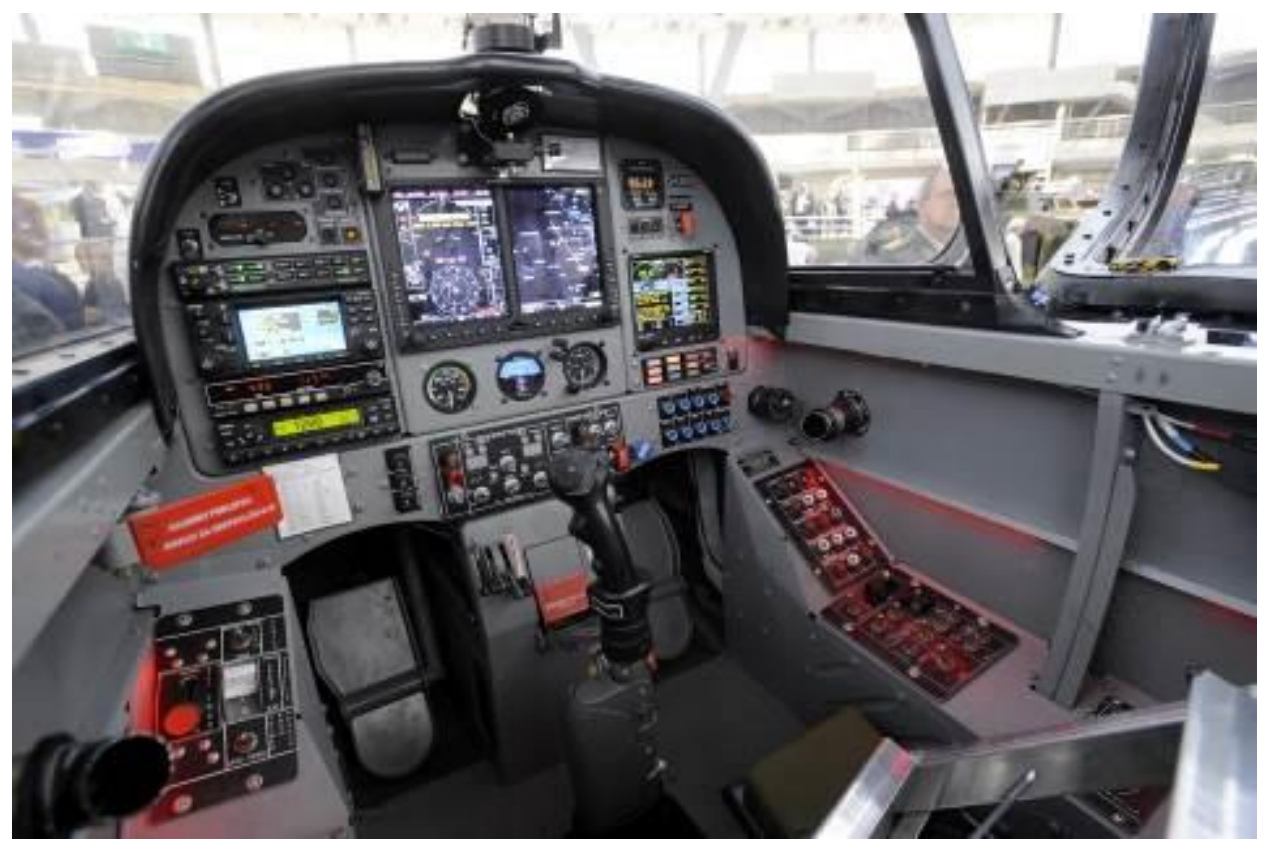

Figure 2 - Digital cockpit of the Lasta aircraft

Puc. 2 - Стеклянная кабина самолета „Ласта“

Слика 2 - Дигитални кабински простор авиона „ласта” 
Lasta's glass cockpit includes the most modern navigation and communications equipment currently available on the market for this category of aircraft. Although the flight characteristics of the Lasta aircraft are adapted to beginners, the technical level of the aircraft equipment mentioned above requires a great effort towards achieving the required level of confidence and safe operating. It was necessary to make adaptations of the methodological manuals, the study curriculum and the syllabus concerning the Lasta airplane, as well as many other elements of the flight training system.

\section{Digital glass cockpit}

A glass cockpit is an aircraft cockpit that features electronic (digital) instrument displays, typically large LCD screens, rather than the traditional style of analog dials and gauges. While a traditional cockpit is based on numerous mechanical gauges to display information, a glass cockpit uses several displays driven by flight management systems that can be adjusted to display flight information as needed. This simplifies aircraft operation and navigation and allows pilots to focus only on the most pertinent information (Ison, 2016). A glass cockpit is the core of the Technologically Advanced Aircraft (TAA) which is a modern term used to describe light aircraft with advanced equipment on board, specifically advanced avionics like GPS and glass panel displays.

Glass cockpit displays rely on computerized systems that integrate multiple data inputs and controls. Glass cockpit displays can present more information in the space required for conventional instrument panels, but the increase in information places greater demands on pilot's attention and creates a risk of overloading pilots with more information than they can effectively monitor and process. The complexity of the integrated computerized systems that drive glass cockpit displays may also limit pilots' understanding of the functionality of the underlying systems (National Transportation Safety Board, 2010).

The analysis of both the cockpit layouts and their benefits and disadvantages points out to a few facts (Vlacic et al, 2014):

- The information in a digital glass cockpit is more precise and, due to computer screens, can be displayed much more ergonomically;

- Glass cockpits have a tremendous amount of information available to pilots, which is not available from cockpits with analog gauges;

- Disadvantages of traditional analog instrumentation are the multitudes of mechanical components so glass cockpits also provide an element of maintenance simplicity; 
changes in airspeed and altitude;

- Pilots with glass panels may also be spending more time looking at the displays instead of looking outside;

- In case of turbulence and emergencies, pilots using glass cockpits may touch and activate wrong buttons because there are so many of them in a small area;

- Flying a glass cockpit aircraft requires a different cognitive style of thinking.

It can be concluded that if we want to attain a desired level for safe flying with a glass cockpit, ground training with the use of synthetic devices is also necessary. The process of re-training pilots trained in traditional analog cockpits will not be so easy and fast and it takes time which has to be determined in the next phase of acquiring the Lasta fleet. Because of the cockpit complexity and our study program curriculum timeline, it will be impossible to use the Lasta in the process of selecting future pilots in the primary flight training phase.

In today's fully integrated cockpit, learning how to use these new tools effectively, while still maintaining the control of the aircraft, is something that will keep the training squadron busy for years to come. For pilots who are going to be converted to a glass cockpit and want to gain numerous advantages of modern avionics, there are a number of training options. Many suppliers provide Internet-downloaded trainers free of charge, and there are free online interactive courses. Commercial DVDs and training simulators are extremely useful, too. However, realistic flight training using the specific system in busy airspace during less-than-ideal weather with an experienced flight instructor is a must. (Decker, 2013)

Also, manufacturers of the before mentioned equipment provide only a small part of educational software (for each device separately), but such educational software is not tailored to the specific layout of Lasta's cockpit (Vlačić, 2011).

\section{Digital training}

It is important to understand the difference between learning and training. They are inextricably linked, but they are unique aspects of any educational process. Training is the giving of information and knowledge, through speech, the written word or other methods of demonstration in a manner that instructs the trainee. Learning is the process of absorbing 
that information in order to increase skills and abilities and make use of it under a variety of contexts.

The quality of learning will rely largely on the quality of training.

Training focuses more on the development of new skills or skill sets that will be used. Training is the process each new trainee (cadet) goes through when joining a flight squadron to learn how to carry out day-today operations, know how their airplane works and how job-specific tools operate in order to carry out their responsibilities. In essence, through training, the goal is not to reshape the behavior of an individual rather the point is to teach the cadet how things are done so that they can then carry out a process on their own.

Digitalization is today an inevitable part of any learning or training proccess, especially in modern aviation. There are many definitions of what digital learning is, but a clear definition of digital training is lacking.

Digital learning is "learning facilitated by technology that gives students some element of control over time, place, path and/or pace" (GOSA, 2021). Also, digital learning is any type of learning that is accompanied by technology or by instructional practice that makes effective use of technology. Digital technologies are electronic tools, systems, devices and resources that generate, store or process data (Victoria State Government, 2021). Digital learning is sometimes confused with online learning or e-learning; digital learning encompasses the aforementioned concepts. Digital learning requires a combination of technology, digital content, and instruction.

Technology is the mechanism that delivers content. It facilitates how students receive content. It includes Internet access and hardware, which can be any Internet access device - from a desktop to a laptop to an iPad to a smartphone. Technology is the tool, not the instruction.

Digital content is the high-quality academic material delivered through technology. It is what students learn. It ranges from new engaging, interactive and adaptive software to classic literature, from video lectures to games. It is not simply a PDF file of a text or a PowerPoint presentation.

However, there is no distinctive definition of digital training. Some sources indicate that it is an evolution of e-learning that uses the Internet to make online training courses. Computers, tablets, mobiles or even connected objects, are all means to easily access this type of training. Nevertheless, digital training has much broader contest.

For the purpose of this paper, we consider digital training to be training which includes a variety of digital devices in order to improve the 
quality of flight training, having in mind the previously mentioned differences between learning and training.

\section{Implementation of the digital training concept}

Aircraft manufacturers usually deliver training aircraft to the end user with a wide spectrum of additional training devices (Vlačić et al, 2015), but the developer of the Lasta has not provided training devices and simulators yet. The Military Academy staff had to develop or procure the whole spectrum of training devices in order to make the training process more effective. These devices are part of the set that makes up the concept of digital training on the Lasta airplane. In the meantime, cockpit digitalization has become reality in a few new acquisitions, including the Airbus $\mathrm{H}-145 \mathrm{M}$ utility helicopter or the Mi-35M combat helicopter. In this way, acquisition and equipment with adequate devices for pilot training become a necessity and one of the priorities in aviation modernization (Vlačić et al, 2015).

The main changes in the flight training process occured due to new airplanes equipped with modern hardware and software in different domains. This is most obvious in the aircraft cockpit layout. The main goal of their incorporation was a higher level of flight safety, better efficiency of training and, most importantly, higher combat efficiency of the airplane as a platform. Higher demands placed in front of trainees were somewhat compensated with a wide use of flight trainers/simulators and other digital training devices. Their use in modern training is inevitable. For many years, training devices were developed and produced exclusively by original manufacturers. This led to high prices, caused by industrial monopoly and the application of rigid industrial and military standards. Remarkable development of hardware and software has made these items more affordable than ever if price and performances are considered. This fact opened the door for less specialized personnel to create and develop some training devices. The great change was also made by wide recognition and involvement of Commercial off-the-shelf (COTS) components in the process of creating systems for military use. These facts enabled less experienced staff to create their own digital devices and their own approach to the creation of the digital training concept.

The focus of the use of digital devices has been placed on basic training. The nature of basic flight training requires not only acquiring basic knowledge and skills but a student in training also has to "to learn how to learn". "Inserting" a student-pilot in a real cockpit without 
introduction and adaptation to digital devices reduces the effectiveness of training in many ways.

In creating the concept, the ways of training by which the greatest success is achieved are taken into account. Regardless of different scientific views (Kåre \& Sigbjørn, 2018), it is undeniable that a high level of adaptation of knowledge and skills is achieved through one's own practice and repetition of actions and procedures, instead of simply listening and watching.

Digital training has to be divided in several levels in accordance with training objectives i.e. what specific and useful knowledge, skills, and techniques have to be developed in certain phases of training.

The digital concept in basic flight training contains several levels including:

Interactive learning materials;

Flight Simulator based on commercial software;

Virtual reality (VR) devices;

Learning Management System (LMS);and

Other training hardware and software.

\section{Interactive learning materials}

Today there is a broad range of interactive learning materials which provide cadets - pilots with the aviation knowledge they require to prepare for theoretical examinations and to become safe and competent pilots. After evaluation, the Military Academy opted for the CAE Oxford Aviation Academy interactive materials in compliance with the EASA ${ }^{1}$ standards. These materials have the form of full color textbooks and multimedia computer-based training (CBT), both comprehensively covering the theory but delivering it in a different way.

Within CBT, each lesson is accompanied by clear precise narration which leads students through each essential teaching point. The lessons are built with an effective combination of graphics, animations, audio voice-overs, textual key-points and revision questions, providing a unique and effective way of mastering difficult concepts in an engaging way.

During the six years of CBT application, cadets demonstrated better results $^{2}$ in subjects in which CBT were used. The comprehensible manner gave cadets a lot of good examples and advice on how to deal with problems in future flight training.

\footnotetext{
${ }^{1}$ EASA - European Aviation Safety Agency

2 according to the Military Academy evaluation process
} 
Also, embedding new cockpit instruments imposed new training approaches. Because of the Garmin origin, the Military Academy introduced the dedicated Garmin software and hardware simulator for its complex devices such as Garmin G500/600. The basic variants of this simulator can be viewed and downloaded at the Garmin support pages (Garmin, 2021). This simulator allows cadets to perform basic functions within the Garmin system. It is possible to learn how to input data and frequencies using tips and tricks for "best practices". Cadets learn to navigate using flight plans and GPS direct courses. They are able to navigate pages and page groups of the Flight Management System, while recognizing the most important functions using tips and tricks. The first generation of cadet pilots who started their flight training after practicing on this simulator shows better performance in the basic stages of the flight syllabus.

\section{LMS in the flight training preparation phase}

The Military Academy staff has decided to implement MOODLE elearning platform in the Military Aviation study program (http://adl.elearning.mod.gov.rs/). MOODLE (Modular Object-Oriented Dynamic Learning Environment) is a free source e-learning system shell (LMS), written in PHP. It is an important tool for e-learning and blended learning which provides a framework for preparing courses and for learning over it. Various content is provided over this system shell (texts, pictures, optional files, links, multimedia etc.), but the tasks related to them that can be scored are also important (assigning tasks in the form of online texts, file, varied types of tests, offline tasks, etc.). This system unifies and presents, in a single surface, all the services that are otherwise applied by teachers on parallel surfaces, often offline (sharing documents and information, sending messages, evaluation, etc.) (Namestovski \& Arsovic, 2013).

\section{Microsoft Flight Simulators}

Microsoft Flight Simulator X, also known as FSX, is a 2006 flight simulation computer game originally developed and published by Microsoft for Microsoft Windows. It is the next in the sequence after Microsoft Flight Simulator 2004. This software can be classified as virtual modeling on a computer workstation. One of the enduring problems with any flight simulator is a restricted field of view (FOV) imposed by the computer display screen. This restriction severely limits peripheral vision, which in turn detracts from perceived realism. 
The external graphic card Matrox TripleHead2Go expanded Flight Simulator $X$ across three displays (Figure 3 ), providing a panoramic view that enables users to see more of their virtual cockpit and improves flight visibility at the same time. This extended view provides a more realistic flight experience by fully engaging peripheral vision on the side displays.

As a further level, Microsoft Flight Simulator 2020 was introduced in order to support FSX. Microsoft Flight Simulator 2020 was released in 2020, for Microsoft Windows, with a virtual reality (VR) version. Flight Simulator simulates the topography of the entire Earth using data from Bing Maps. Artificial intelligence (Al) generates three-dimensional representations of Earth's features, using its cloud computing to render and enhance visuals, and real-world data to generate real-time weather and its effects. Flight Simulator has a physics engine to provide realistic flight control surfaces, with over 1,000 simulated surfaces, as well as realistic wind modelled over hills and mountains. Some places are handcrafted, introduced in region-specific updates. To augment its realism, Al also incorporates real-time elements like natural weather and real-world air traffic. The gameplay includes new features such as landing challenges and helpers.

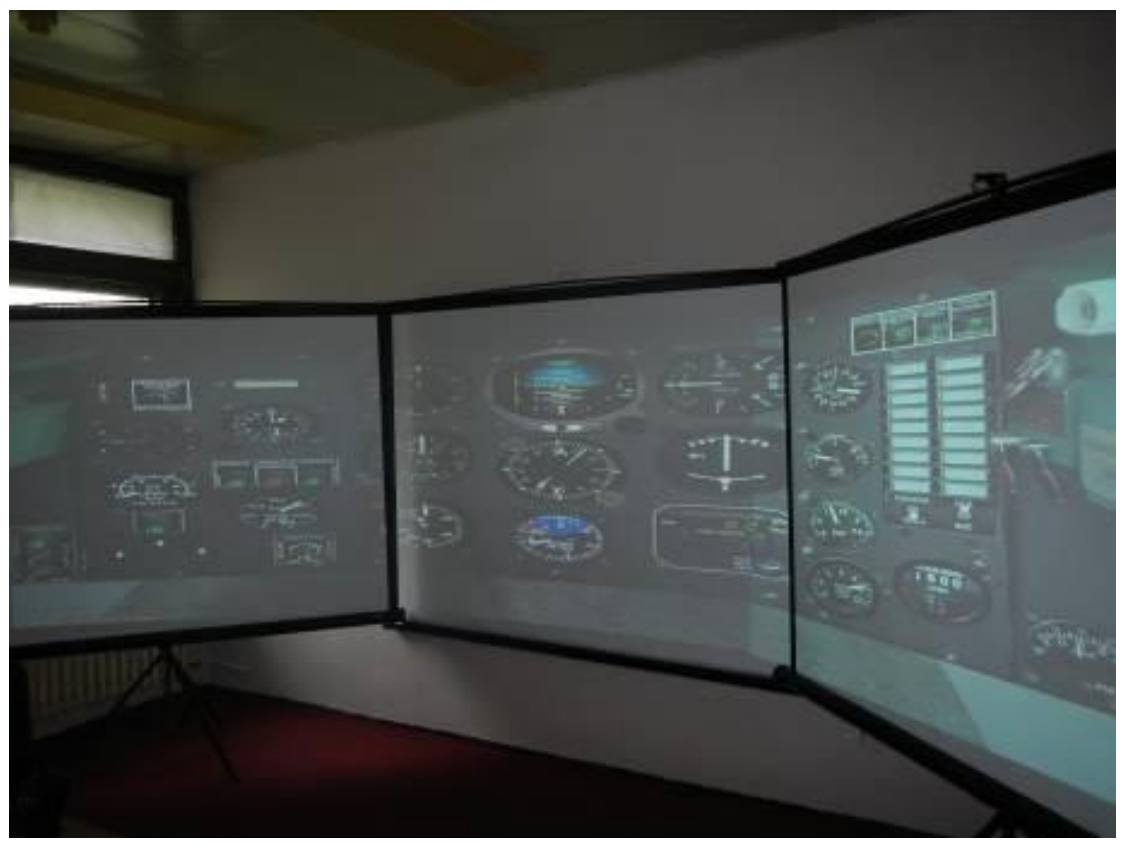

Figure 3 - Expanding FSX across three displays

Pис. 3 - Расширение изображения программы авиасимулятора на трех дисплеях Слика 3 - Проширење приказа програма симулатора летења на три приказивача 
The developer scanned the interiors and exteriors of aircraft with a 3D scanner to create their realistic looks, polished with modeling and printing (Aysha, 2020). There are also realistic physics and weather systems, and utilization of real-world weather data. For instance, if it is raining somewhere in real life, it can rain in-game. Individual clouds have their own behaviors and will impact aircraft performance depending on its location within the system. Flight Simulator is the first flight simulator to enable worldwide visual flight rules (VFR), a feature not seen in contemporary flight simulators used by airlines to train and test pilots.

Through cloud-based technology, Flight Simulator sends data to the computer in real time, with Al being utilized to extrapolate geometry from a blend of satellite and flyover imagery (Jensen, 2020). Other sources of data include terrain data for landscaping, data for foliage density, realtime meteorological data, and air traffic updates. Cloud technology is used to calculate, among other things, the way air flows around natural structures such as mountains to cause pockets of turbulence, or streams in the world's real-time air traffic, and time of day and weather.

Microsoft simulators are mainly used to demonstrate cockpit views and basic systems characteristics in the aircraft used in real flight training. To simulate domestic airplanes (UTVA-75, Lasta, Supergaleb G4) which are not involved in the FSX package, the specific add-ons have been created as a long-term process. Developing one's own add-ons was the first step in creating a basic flight simulator. However, it is important to stress that during the flight-training phase in military jets (G4 Supergaleb in our case) a full-scale flight simulator is used. The use of a full flight simulator is expensive and impracticable in the basic training phase, which is our point of consideration.

When speaking about the assessment and worthiness of the kind of software such as Microsoft simulators, we have to mention what kinds of simulators and simulations exist on the market. Simulations can consist of virtual modeling on a computer workstation, part task devices with actual system hardware and software, or full-mission man-in-the-loop simulators with visual systems and motion. All have their place in the process, and all play a role in shortening development time and cost (Vlačić, 2011).

Both versions of Microsoft Flight Simulators have been procured for the training process in the Military Academy. The main advantages are not only visual simulation but the possibility to connect many modern peripherals such as virtual reality and eye tracking devices. 


\section{VR devices}

Virtual reality (VR) has been developed to facilitate human immersion into new computer-generated synthetic environments that block out the real world. Recent advancements in VR technologies enable users to interact with high resolution three-dimensional graphics without any significant video delay. This technological advancement for VR systems has reinforced its professional training applications, including those for aircraft pilots. Conventional flight simulator systems can generate realistic situational conditions, installing out-the-window scenery screens in front of their mockup cockpits with motion platforms, but the setting at such a level, which is costly and requires a $360^{\circ}$ angle of-scenery screen, is still hard to implement. VR has the advantage of implementing the $360^{\circ}$ angle-of horizontal - and vertical-scenery view for a lower cost.

Pilots are exposed to a lot of safety-critical situations, and they have to practice recovery skills against all potentially dangerous situations. VR can show a better performance for this kind of dangerous situation training than conventional simulators due to its higher realism. Pilots also have to develop skills to manipulate modern electronic cockpit systems, including setting the objective heading direction on the electronic compass, magnifying/demagnifying the electronic map display, and switching communication radio frequencies with other channels. The high-cost conventional mockup simulators install the actual electronic cockpit hardware, for which all functionalities can be manipulated by manual controls (Chang-Geun, 2020).

The main benefit of virtual reality in flight training is the immersive representation of the flight experience, providing some important learning advantages over traditional flight simulators. The key benefits for flight schools include reduced training costs, cost savings on aircraft familiarization training, and faster training of students.

Virtual Reality (VR) is the concept of being immersed into a computer-generated environment with a visual, audible and optionally haptical representation of the environment. This environment, e.g. a room, landscape or a cockpit, may be presented to the user through a screen or a head mounted display (headset). The user may be able to interact with the environment, e.g. through gestures or physical buttons or levers.

VR offers new opportunities for significant improvement of teaching and learning as subjects can be taught/learnt in a very different way instead of reading a textbook or listening to a lecturer. 


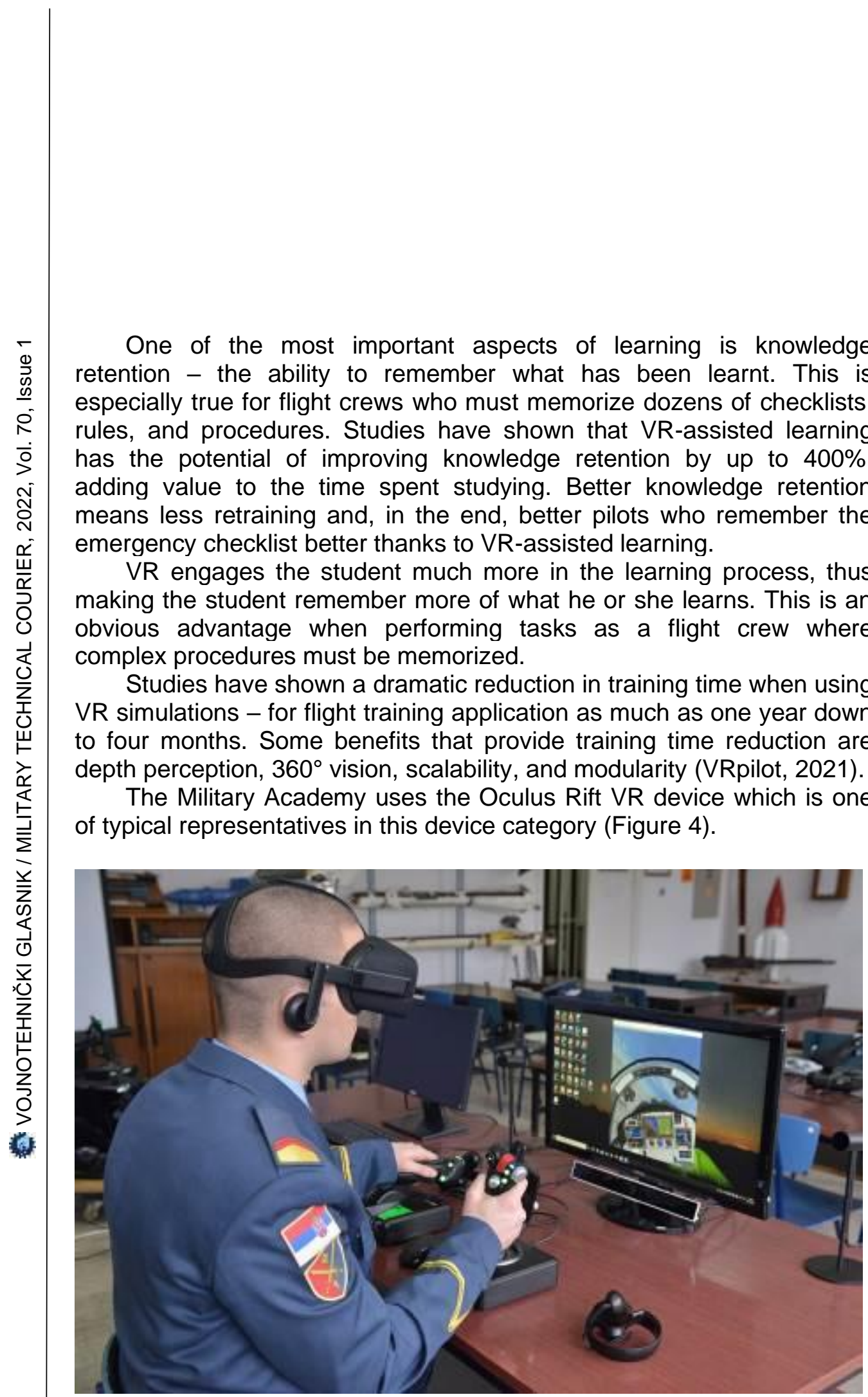

Figure 4-Oculus Rift VR in basic flight training

Puc. 4-Oculus Rift VR в основной летной подготовке Слика 4 - Oculus Rift VR у основној летачкој обуци 
The Oculus Rift VR headset uses gaze tracking and IR LED sensors to identify the user's position and, at the same time, to interact with the virtual environment. Users can move freely within their physical environment - sit, stand, walk, turn, duck, and dodge as they desire. Similarly, it is possible to simulate the aerial environment as well as the image of the aircraft cockpit. A VR headset enables a stereo image of the pilots' workspace and gaze sweeping inside and outside the cockpit. The headset has an OLED display with 2060 X 1200 resolution and a $90 \mathrm{~Hz}$ refresh rate. The field of view (FOV) is $110^{\circ}$ and the tracking area is 12.7 by $27.94 \mathrm{~cm}$. The sensors include accelerometers, gyroscopes, and magnetometers. The system enables full 360-degree positional tracking.

\section{Other training hardware and software}

The commercial flight simulator created in the Military Academy provides connection for many other devices that can be used in cadets' training and evaluation. The most important is the GP3 Desktop Eye Tracker device.

In nearly all human-computer interactions, the most basic point of connection between an interface and its user is the eye. Eye tracking has been an important source of information about perception and cognition for more than 50 years. It has been utilized to study a diverse number of topics such as the patterns of fixations and saccades while reading a text, the workload of pilots during different phases of flight, the application of different scan patterns in flight training, the role of pilots' monitoring strategies in flight performance and the effectiveness of visual advertisements among many others. In the Military Academy case, pilot's eye movement patterns are recorded by using the GP3 Desktop Eye Tracker. The GP3 Desktop Eye Tracker is a complete eye tracking system used as a device for measuring eye positions and eye movement.

The role of the GP3 Desktop Eye Tracker is to make assessment during flight simulation. The assessment is done regarding the senses and skills necessary for flying as well as piloting skills in the air. The Piloting techniques are assessed in the air according to standard practices for monitoring, assessment, and evaluation.

Assessment helps cadets to improve their ability to successfully cope with the flight syllabus and develop the required pilot aptitudes.

The biggest contribution of this kind of equipment is in improving the pilot selection process using eye tracking tools (Vlačić et al, 2019).

The Sky Demon is one of numerous electronic flight bag software programs available on the market. It enables flight planning as well as 
GPS navigation in the air. Its special features include real-time updates of aeronautical information. For navigation training purposes only, the internal simulation software, called the X-plane, enables the simulation of the flight along the planned route. Furthermore, it is possible to connect the Sky Demon in the simulation mode with Microsoft Flight Simulator via the FSX2SkyDemon application available on the Google Play Store. This small application receives the data from the FSX software and presents the information about the aircraft performance and position in the form of a track plot on top of the Google Earth maps. At the same time, it forwards the data to the Sky Demon software and makes it look like the user is flying a real airplane. Real-time aeronautical information from the Sky Demon, especially the information about the wind has a feedback impact on the aircraft performance in FSX.

For navigation training, the Sky Demon software installed on a tablet is connected with Microsoft Flight Simulators (Figure 5).

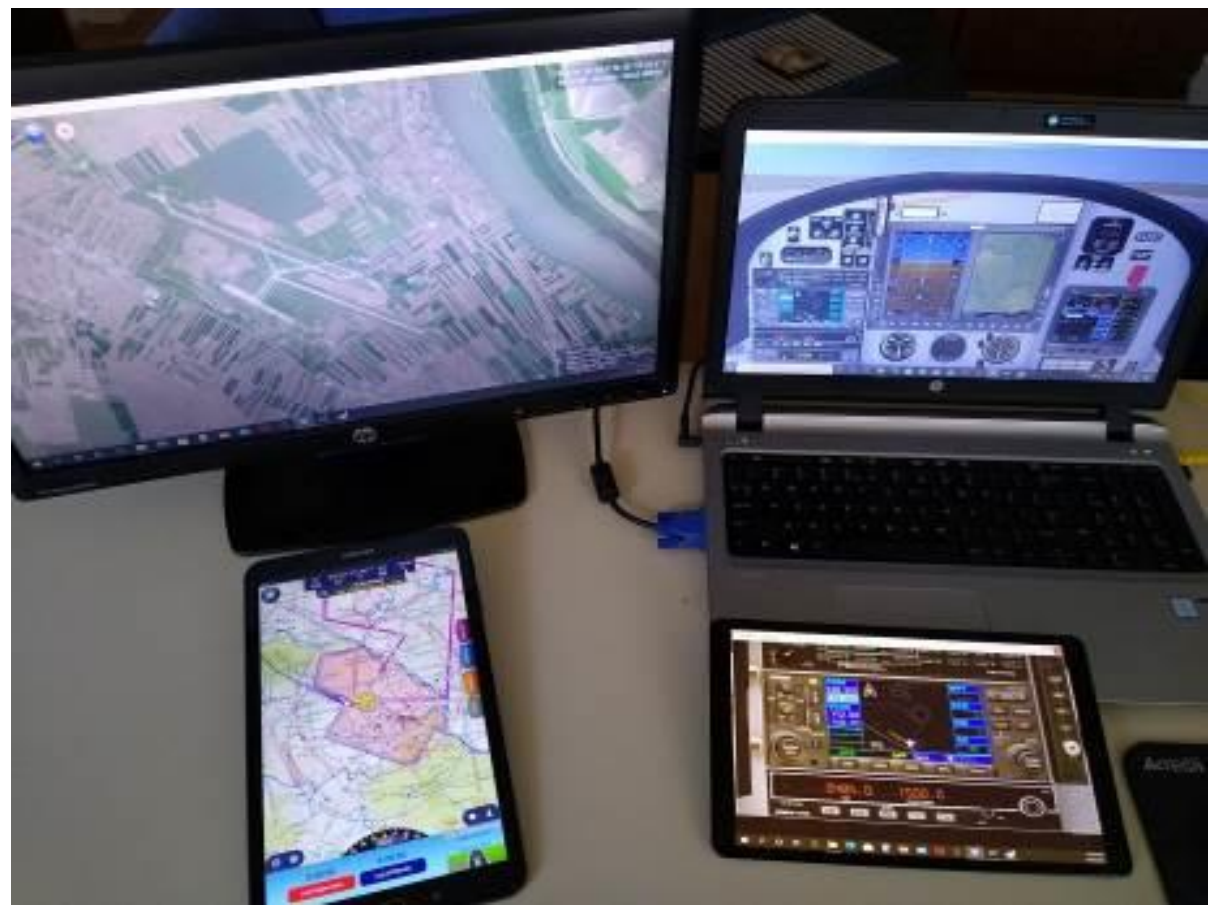

Figure 5 - Connection of the Sky Demon tablet with Microsoft Flight Simulators Puc. 5 - Подсоединение планшета с программой Sky Demon к авиасимулятору Microsoft Flight Simulators

Слика 5 - Повезивање таблета који поседује програм Sky Demon са програмом Microsoft Flight Simulator 
Diversity and fine balance of devices used in the showed digital concept provided a step forward into better basic flight training. According to internal documents, there were no failures in basic flight training after the implementation of the digital training concept.

\section{Conclusion}

Basic flight training is considered as the most important phase of flight training and a core of a successful process of making future military pilots. This training phase has experienced significant changes with the introduction of the Lasta piston engine trainer which belongs to the Technically Advanced Aircraft category. This aircraft is characterized by a high degree of cockpit digitalization and aircraft systems as a whole. The technical level of the Lasta aircraft equipment requires a great effort towards achieving a required level of confidence and safe operation. In order to attain a desired level of safe flying with a glass cockpit, ground training with the use of digital synthetic devices is also necessary.

The developer of the Lasta has not provided training devices and simulators yet. The Military Academy staff developed and procured a whole spectrum of training devices in order to make the training process more effective. Digital training as a type of training includes a variety of digital devices in order to improve the quality of flight training. In the case of basic flight training in the Military Academy, the digital concept of training consists of:

Interactive learning materials;

Flight Simulator based on commercial software;

$V R$ devices;

LMS; and

Other training hardware and software.

The first generation of cadets - pilots who started their flight training after practicing on this simulator shows a better performance in the basic stages of the flight syllabus. The COTS based simulator was the core for other peripherals.

VR offered new opportunities to significantly enhance the flight training process. Cadets learn faster and more efficiently while remembering the lessons taught better.

The GP3 Desktop Eye Tracker has proved to be an assessment tool during the simulated flight training. Assessment is done regarding the senses and skills necessary for flying and piloting skills in the air. The biggest contribution of this kind of equipment is in the improvement of the pilot selection process using eye tracking tools. 
espite the fact that the digital training concept is not mandatory in the existing flight training model in the Serbian Military Academy, it proves valuable. Its potential is considerable, and, to a certain extent, it can change the nature of basic flight training. Due to the digital training concept, cadets can fly more safely and their flying skills are acquired faster.

\section{References}

Aysha, M. 2020. Microsoft Flight Simulator made more realistic thanks to 3D scanning. 3Dnatives, 27 October [online]. Available at: https://www.3dnatives.com/en/microsoft-flight-simulator-271020205/\# [Accessed: 20 October 2021].

Chang-Geun, O. 2020. Pros and Cons of A VR-based Flight Training Simulator; Empirical Evaluations by Student and Instructor Pilots. Proceedings of the Human Factors and Ergonomics Society Annual Meeting, 64(1), pp.193197. Available at: https://doi.org/10.1177/1071181320641047.

Decker, T. 2013. Glass Cockpit Flight Training. Aviator college's Blog, 10 April [online]. Available at: http://aviatorcollege.wordpress.com/2013/04/10/glass-cockpitflight-training/ [Accessed: 7 July 2021].

-Garmin. 2021. G500/G600 Series Trainer Base Install software version 1.2.0 [online]. Available at: http://www8.garmin.com/support/download_details.jsp?id=4867 [Accessed 15 October 2021].

-GOSA (The Governor's Office of Student Achievement). 2021. What is Digital Learning? [online]. Available at: https://gosa.georgia.gov/about-us/whatdigital-learning [Accesed 28 September 2021].

Ison, D. 2016. Is Glass Safer? Plane \& Pilot, 6 February [online]. Available at: https://www.planeandpilotmag.com/article/is-glass-safer/ [Accessed: 20 October 2021].

Jensen, K.T. 2020. Why Microsoft Flight Simulator 2020 Is This Year's Most Ambitious Game. PCMag, 18 August [online]. Available at: https://sea.pcmag.com/computer-console-gaming/38658/why-microsoft-flightsimulator-2020-is-this-years-most-ambitious-game [Accessed: 20 October 2021].

Kåre, L. \& Sigbjørn, H. 2018. Excavating the origins of the learning pyramid myths. Cogent Education, (5) 1 , pp.1-17. Available at: https://doi.org/10.1080/2331186X.2018.1518638.

Namestovski, Z. \& Arsovic, B. 2013. Possibilities of implementing web 2.0 tools in education. In: International Conference on Information Technology and Development of Education - ITRO 2013, Proceedings, Zrenjanin, pp.43-45, June [online]. Available at: http://www.tfzr.rs/itro/Zbornik2013.pdf [Accessed: 20 October 2021].

-National Transportation Safety Board. 2010. Introduction of Glass Cockpit Avionics into Light Aircraft, Safety Study [online]. Available at: https://www.ntsb.gov/safety/safety-studies/Documents/SS1001.pdf [Accessed: 20 October 2021]. 
-Victoria State Government. 2021. Teach with digital technologies [online].

Available

https://www.education.vic.gov.au/school/teachers/teachingresources/digital/Pag es/teach.aspx\#: :text=Digital\%20technologies\%20are\%20electronic\%20tools,ac ross\%20all\%20curriculum\%20learning\%20areas [Accesed: 28 September 2021].

Vlacic, S., Rodjenkov-Milinkovic, S., Knezević, A. \& Vlacic, I. 2014. Use of the commercial software tools in the preparation phase of military pilot education and training. In: International Conference on Information Technology and Development of Education - ITRO 2014, Proceedings, Zrenjanin, pp.346-350, June [online]. Available at: http://www.tfzr.rs/itro/Zbornik_ITRO_2014.pdf [Accessed: 20 October 2021].

Vlačić, S. 2011. Training devices and flight simulators variants of application in pilots training on the aircraft Lasta. In: $4^{\text {th }}$ International scientific conference on defensive technologies OTEH 2011, Belgrade, pp.143-146, October 6-7 [online]. Available at: http://www.vti.mod.gov.rs/oteh11/index.htm [Accessed: 20 October 2021].

Vlačić, S.I., Knežević, A.Z., Mandal, S., Rođenkov, S. \& Vitsas, P. 2019. Improving the pilot selection process by using eye-tracking tools. Journal of Eye Movement Research, 12(3). Available at: https://doi.org/10.16910/jemr.12.3.4.

Vlačić, S., Knežević, A. \& Milutinović, M. 2015. Application of commercial available hardware in the making of flight trainer International Conference on Information Technology and Development of Education - ITRO 2015, Proceedings, Zrenjanin, pp.284-289, June [online]. Available at: http://www.tfzr.rs/itro/Zbornik\%20ITRO\%202015.pdf [Accessed: 20 October 2021].

-VRpilot. 2021. Virtual Reality \& Flight Training [online]. Available at: https://vrpilot.aero/virtual-reality-flight-training/ [Accessed: 17 October 2021].

\section{ВНЕДРЕНИЕ КОНЦЕПЦИИ ЭЛЕКТРОННОГО ОБУЧЕНИЯ В ПРОГРАММУ ОСНОВНОЙ ЛЕТНОЙ ПОДГОТОВКИ В ВОЕННОЙ АКАДЕМИИ РЕСПУБЛИКИ СЕРБИЯ}

Славиша И. Влачича , корреспондент, Александар 3. Кнежевича Владимир М. Грбовичб ${ }^{\text {, Панос А. Витсас }}$, Михайло (Майк) С. Михайловичг

а Университет обороны в г. Белград, Военная академия, Кафедра военной авиации, г. Белград, Республика Сербия

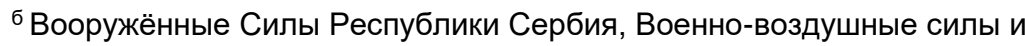
Противовоздушная оборона (ВВС и ПВО),

г. Белград, Республика Сербия

в Международная школа летчиков-испытателей, г. Лондон (Онтарио), Канада

г Правительство Онтарио, г. Торонто, Канада; MRTD Defense Eng, г. Торонто, Канада 


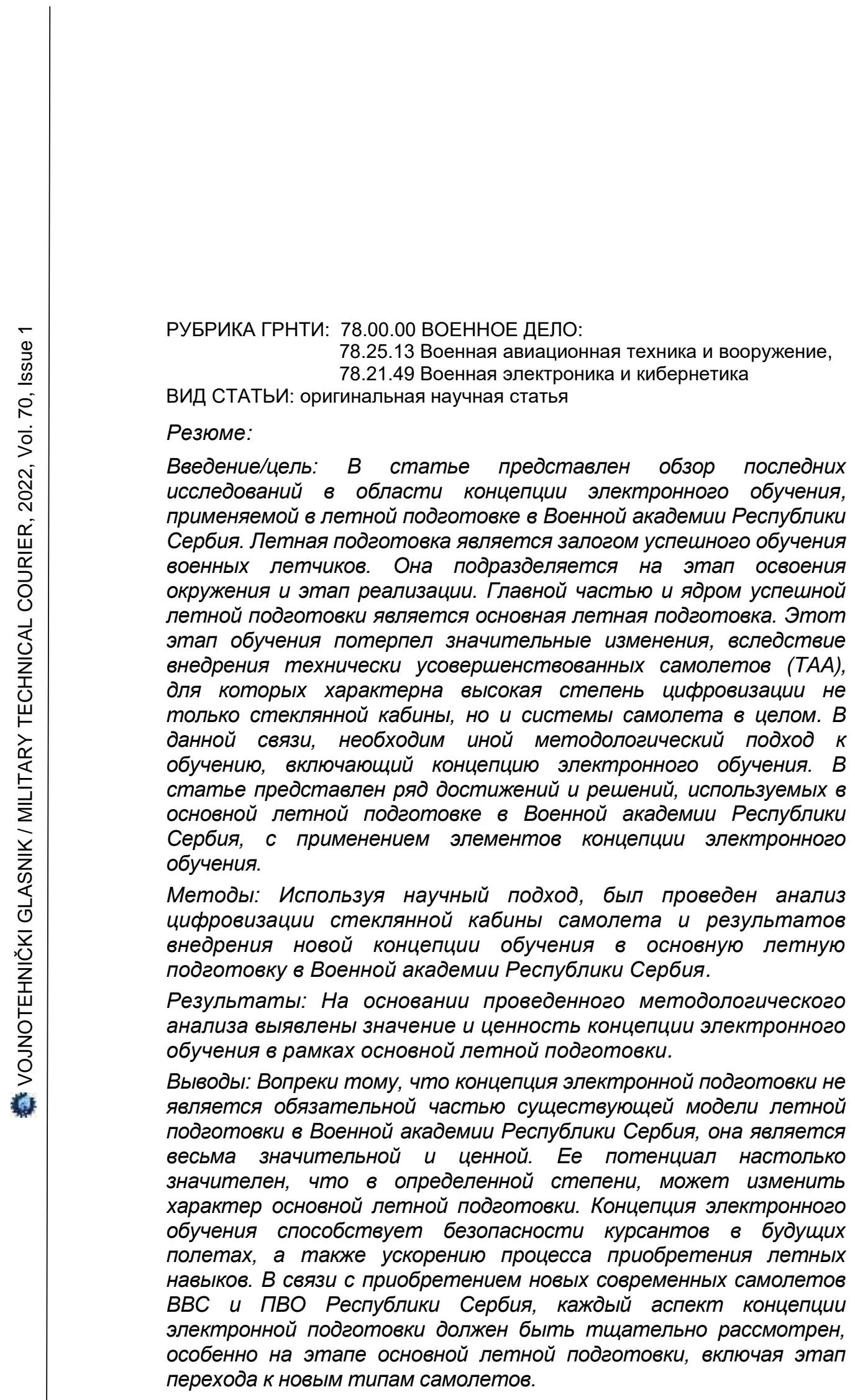

Ключевые слова: летная подготовка, стеклянная кабина, электронное обучение, учебные средства. 
ПРИМЕНА КОНЦЕПТА ДИГИТАЛНЕ ОБУКЕ У ОСНОВНОЈ ЛЕТАЧКОЈ ОБУЦИ НА ВОЈНОЈ АКАДЕМИЈИ

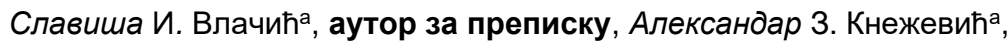
Владимир М. Грбовићб ${ }^{\sigma}$ Панос А. Витсас ${ }^{\mathrm{B}}$, Михајло (Мајк) С. Михајловић

а Универзитет одбране у Београду, Војна академија,

Катедра војног ваздухопловства, Београд, Република Србија

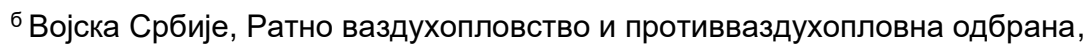
Београд, Република Србија

в Међународна школа за опитне пилоте, Лондон (Онтарио), Канада

г Влада Онтарија, Торонто (Онтарио), Канада;

MRTD Defense Eng, Торонто (Онтарио), Канада

ОБЛАСТ: ваздухопловство, информационе технологије

ВРСТА ЧЛАНКА: оригинални научни рад

Сажетак:

Увод/циљ: У раду су представљена недавна истраживања у области концепта дигиталне обуке примењеног у летачкој обуци на Војној академији Републике Србије, која чини основу успешног образовања војних пилота. Њена подела заснована је на окружењу и фрази реализације. Главни део и основу успешне летачке обуке представља основна летачка обука. Ова фраза обуке доживела је значајне промене увођењем технички напредних авиона (TAA) који се одликују високим степеном дигитализације кабинског простора и система авиона у целини. Сходно томе, потребан је другачији методолошки приступ обуци, укључујући концепт дигиталне обуке. Приказана су достигнућа и поједина решења која се користе у основној летачкој обуци на Војној академији, уз примену елемената дигиталних концепата обуке.

Memoде: Користећи научни приступ извршен је увид у дигитализацију пилотских кабинских простора и имплементације новог концепта у основну летачку обуку на Војној академији Републике Србије.

Резултати: На основу примењене методе анализе приказани су значај и вредности концепта дигиталне обуке у основној летачкој обуци.

Закључак: Иако концепт дигиталне обуке није обавезан у постојећем моделу летачке обуке на Војној академији Србије, показало се да је веома значајан. Његов потенцијал је велики и, до одређеног нивоа, може променити карактер основне летачке обуке. Захваљујући концепту дигиталне обуке, кадети касније могу безбедније управљати летелицама и брже стицати летачке вештине. У складу са набавком нових савремених авиона у Ратном ваздухопловству и противваздухопловној одбрани Војске Србије,

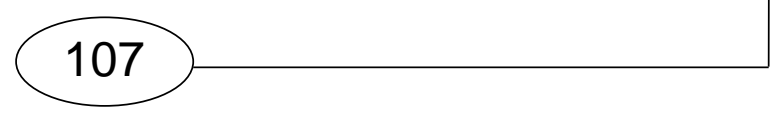


сваки аспект концепта дигиталне обуке мора се пажљиво размотрити, посебно у фрази основне летачке обуке, укључујући и фразе преласка на нове типове авиона.

Кључне речи: летачка обука, стаклени кабински простор, дигитална обука, средства за обуку.

Paper received on / Дата получения работы / Датум пријема чланка: 26.10.2021.

Manuscript corrections submitted on / Дата получения исправленной версии работы / Датум достављања исправки рукописа: 03.01.2022.

Paper accepted for publishing on / Дата окончательного согласования работы / Датум коначног прихватања чланка за објављивање: 04.01.2022.

(C) 2022 The Authors. Published by Vojnotehnički glasnik / Military Technical Courier

(www.vtg.mod.gov.rs, втг.мо.упр.срб). This article is an open access article distributed under the terms and conditions of the Creative Commons Attribution license (http://creativecommons.org/licenses/by/3.0/rs/).

(c) 2022 Авторы. Опубликовано в «Военно-технический вестник / Vojnotehnički glasnik / Military Technical Courier» (www.vtg.mod.gov.rs, втг.мо.упр.срб). Данная статья в открытом доступе и распространяется в соответствии с лицензией «Creative Commons» (http://creativecommons.org/licenses/by/3.0/rs/).

(c) 2022 Аутори. Објавио Војнотехнички гласник / Vojnotehnički glasnik / Military Technical Courier (www.vtg.mod.gov.rs, втг.мо.упр.срб). Ово је чланак отвореног приступа и дистрибуира се у складу са Creative Commons licencom (http://creativecommons.org/licenses/by/3.0/rs/). 